\title{
Utopijska ideja obnove svijeta u putopisu »Simfonije Jadrana, Italije, Pariza i Londona « Josipa Kosora
}

\author{
Sanja Knežević* \\ sknezev@unizd.hr \\ https://orcid.org/0000-0003-0582-4298
}

\author{
https://doi.org/10.31192/np.19.2.12 \\ UDK: 821.163.42-992Kosor, J. \\ 111.852:82 \\ Prethodno priopćenje / Preliminary communication \\ Primljeno: 4. siječnja 2021. \\ Prihvaćeno: 18. veljače 2021.
}

U radu se interpretira putopis »Simfonije Jadrana, Italije, Pariza i Londona" Josipa Kosora u ključu avangardne utopijske ideje obnove svijeta. Kosorov »transcendentni utopizam " (Oraić Tolić) interpretirat će se na primjeru specifičnoga, hibridnog putopisnog žanra i to interpretacijskim čitanjem dominanti koje uvjetuju njegovu utopijsku misao - estetika (pejzaž), duhovnost (umjetnost), moral (sloboda). Interpretacijom se u tom smislu želi dokazati da je Josip Kosor već na izmaku avangardno-ekspresionističkih strujanja u hrvatskoj književnosti ostao vjeran utopijskoj ideji o obnovi svijeta.

Ključne riječi: estetika, duhovnost, hrvatski putopis, Josip Kosor, moral, utopija.

\section{Uvod}

U ovom se radu promišlja i interpretira putopis »Simfonije Jadrana, Italije, Pariza i Londona « Josipa Kosora kroz dimenziju avangardnog utopizma. Kosor u svom, više od sedamdeset godina javnosti nedostupnom putopisu, zastupa ideju o obnovi svijeta ljudskim povratkom vjeri u estetiku, duhovnost i moral. Ovi pojmovi nameću se kao dominante unutar njegova putopisna iskaza pa ćemo ih nastojati analizirati po načelu: a) estetika - ljepota pejzaža u jadranskim putopisima; b) duhovnost - uzvišenost umjetnosti i umjetničkoga genija u talijanskim putopisima; c) moral - sloboda i disciplina kao uzoran oblik društvenog uređenja u pariškim i londonskim putopisima. Prije same in-

\footnotetext{
* Izv. prof. dr. sc. Sanja Knežević, Sveučilište u Zadru, Odjel za kroatistiku, Obala kralja Petra Krešimira IV., br. 2, HR-23000 Zadar.
} 
terpretacije putopisa »Simfonije Jadrana... « Kosorovo se književno djelo nastoji kontekstualizirati u hrvatskoj književnoj historiografiji s osobitim osvrtom na njegova avangardno-ekspresionistička obilježja koja su kod ovoga autora zamijetili i većim dijelom obradili na temelju njegova isključivo književna opusa (drame, lirika, proze) D. Jelčić, C. Milanja i I. Matičević. Avangardni utopizam te osobito ideje mesijanizma, »cjelokupne umjetnine« i uopće »transcendentnog utopimo « razmatraju se na temelju znanstvenih spoznaja D. Oraić Tolić, C. Milanje i I. Matičevića.

\section{Književni rad Josipa Kosora u kontekstu stilskih formacija prve polovice 20. stoljeća}

Josip Kosor (1879-1961) dramom Požar strasti iz 1912. nastupa kao anticipator novih avangardnih, u prvom redu ekspresionističkih stilova. Promatrajući njegovo djelo u cjelini od prvih lirskih ostvarenja, uspješnih drama i po književnoj povijesti manje uspješnih proza, poetiku Josipa Kosora ne bismo mogli okarakterizirati u potpunosti ni kao modernističko-simbolističku, ni ekspresionističku, ni novorealističku ${ }^{1}$ - nego kao osebujnu poetiku prožimanja svih stilova prve polovice 20. stoljeća, ali s jasnim i nedvosmislenim temeljem $\mathrm{u}$ avangardno-utopijskoj ideji obnove svijeta. U Kosorovu književnom djelu, pa i samom putopisu »Simfonije Jadrana..." u, u tom smislu možemo odčitati svih pet »dominantnih ideja hrvatskoga ekspresionističkoga teorijskoga uma «, ${ }^{2}$ kako ih je raščlanio C. Milanja. Dakle, u Kosorovu djelu prepoznajemo: »fenomenološko-ontološki povratak pojavnosti bića i stvari«, »ideju vjere i nade unatoč nelogičnosti«, »ničeovskog Novog Čovjeka«, »apsolut ego-centričnosti subjekta kao slobode i središta svijeta" i konačno "mitopoetsku koncepciju pjesničkoga jezika«. ${ }^{3}$ Pišući o Kosorovoj pjesnički zbirci Bijeli plamenovi u knjizi Pjesništvo hrvatskog ekspresionizma C. Milanja u cjelini ocrtava značajke Kosorove poetike kao ekspresionističke, a njegov se zaključak može primijeniti kao slika dominantnih poetoloških pojava u cjelini književnoga stvaralaštva Josipa Kosora:

\footnotetext{
${ }^{1}$ Miroslav Šicel uvrštava djelo Josipa Kosora (drame »Požar strasti« i gotovo četrdeset godina javnosti nepoznatu dramu »Maske na paragrafima«) u dvije knjige svoje Povijesti hrvatske književnosti - u dio posvećen moderni i dio posvećen hrvatskom ekspresionizmu (usp. Miroslav ŠICEL, Povijest hrvatske književnosti - Moderna, knj. III, Zagreb, Naklada Ljevak, 2005. i Miroslav ŠICEL, Povijest hrvatske književnosti - Ekspresionizam, knj. IV, Zagreb, Naklada Ljevak, 2007).

2 Cvjetko MILANJA, »Utopijske značajke teorijskog uma hrvatskog ekspresionizma«, u: C. MILANJA (ur.), Ekspresionizam u hrvatskoj književnosti i umjetnosti. Zbornik radova I. znanstvenog skupa s međunarodnim sudjelovanjem (Zagreb 30. XI. - 1. XII. 2001.), Zagreb, altaGAMA, 2002, 47.

${ }^{3}$ Isto.
} 
»Prema tome, može se reći da unutar hrvatskoga ekspresionizma Kosor njeguje posebnu deističku i pankozmičku 'filozofiju' s uporabom biblijskih i kozmogonijskih motiva, u retoričkom i deklarativnom uresnom ruhu, često i maniriziranom; da njegov iskazni subjekt proizvodi svemirsku inscenaciju kojom lansira lirski subjekt u himničkom, ekstatičnom raspoloženju, opijen htonskom, kaosnom svemirskom melasom u kojem je solarno, kristovsko i kreacionističko načelo pozvano da ustroji i disciplinira strukturu, da osmisli opustošenu zemlju, da u kontingenciji (kaosa) uvede teleogijnost analogijom svemirske božanske harmonije, uz koju 'priliježe' i lirski subjekt značajkom kreacionizma. Tako se uspostavlja fundamentalna Kosorova dihotomija: svemir kao dobro i regulativno strukturotvorno načelo, i zemlja kao povijesna čovjekova dezekologizirana postojbina zla. ${ }^{4}$

Dakle, označnice koje bi se odnosile na poetiku Kosorove poezije, nedvojbeno su prepoznatljive i u drugim književnim rodovima u kojima se ovaj autor okušao. Ovu ćemo tvrdnju nastojati argumentirati u interpretativnoj analizi Kosorova putopisa »Simfonije Jadrana, Italije, Pariza i Londona« nastalog kasnih 30-ih godina prošloga stoljeća, a prvi put objavljena u Djelima Josipa Kosora 2014. godine. ${ }^{5}$ Do tada je Kosor kao putopisac bio zapažen putopisom objavljenim 1926. godine »Atlantikom i Pacifikom« koji se po svojoj egzotičnoj tematici uklapa u putopis »mijene stoljeća $«^{6}$ koji teži otkrivanju novog svijeta po čijoj je slici moguća nova avangardna obnova. Da su Kosorove putopisne »Simfonije...« do objavljivanja 2014. godine bile potpuno nepoznate hrvatskoj književnoj povijesti govori činjenica da ovaj naslov nije zastupljen ni u jednom pregledu hrvatskih putopisa pa čak ni u gotovo leksikonskom pregledu hrvatskih putopisa po Italiji iz pera Zdravke Krpine »Italija očima Hrvata«. ${ }^{7}$ Stoga vjerujemo da će njihova interpretacija u kontekstu književnih poetika prve polovice 20. stoljeća barem malo pridonijeti revalorizaciji nepravedno zaboravljena djela Josipa Kosora.

U monografiji Dubravka Jelčića Avantura strasti, strast avanture (1988.) posvećenoj Kosorovu životu i djelu, Jelčić spominje ovaj Kosorov putopis i djelomično ga obrađuje u poglavlju »Putopisi« držeći kako je u ovoj knjizi

${ }^{4}$ Cvjetko MILANJA, Pjesništvo hrvatskog ekspresionizma, Zagreb, Matica hrvatska, 2000, 136137.

${ }^{5}$ Priređivač Djela Josipa Kosora, Ivica Matičević uz deveti svezak u kojem je objavljen putopis "Simfonije Jadrana, Italije, Pariza, Londona « u Napomeni ističe: »Josip Kosor napisao je dvije knjige putopisa: prva je, pod naslovom Atlantikom i Pacifikom, objavljena 1926. u Zagrebu (...). Druga knjiga, pod naslovom Simfonije Jadrana, Italije, Pariza, Londona, ostala je u rukopisu i u ovim se Djelima objavljuje prvi put. Sa suprugom Ivankom Mitrović, koju autor dosljedno u putopisu naziva Ljubicom, Kosor se 8. studenoga 1938., nakon obilaska dubrovačke okolice i Crne Gore, zaputio iz gruške luke prema Italiji (...). Zapisi o tome višemjesečnom putovanju nastali su 1939., a u ostavštini su sačuvani u strojopisu, s korekturama i jezičnim dopunama ispisanim autorovom rukom « (M. I., »Napomena«, u: Josip KOSOR, Simfonije Jadrana, Italije, Pariza, Londona. Djela Josipa Kosora, sv. 9, Zagreb, Ex libris, 2014, 363).

${ }^{6}$ Usp. poglavlje »Traženje unutarnjeg bića svijeta u putopisu s mijene stoljeća«, u: Ivan PEDERIN, Povijesna poetika putopisa, Split, vlastita naklada, 2009, 370-378.

7 Usp. Zdravka KRPINA, Italija očima Hrvata, Zagreb, Hinus, 2001. 
autor »razvijao svoja ezoterična razmišljanja o napretku čovječanstva i duhu čovjekovu $\ll{ }^{8}$ Već činjenica da je svoje »Simfonije...« u kojima je dominantna utopijska ideja obnove svijeta po načelu vjere u ljepotu, duhovnost i moral, Kosor završio 1939. godine, dakle u prvoj godini Drugoga svjetskog rata, može nas navesti na razmišljanje da je ovaj, premda putopisni tekst, jedan od posljednjih hrvatskih umjetničkih labuđih krikova nad avangardnom idejom utopijske obnove svijeta.

\section{Estetika, duhovnost i moral - dominante Kosorova utopijskog putopisnog diskursa}

Nedvojbena je činjenica da oba Kosorova putopisa pripadaju nefikcionalnoj umjetničkoj prozi te da se više ili manje mogu interpretirati i unutar književnopovijesnog okvira putopisa koji je u hrvatskoj znanosti o književnosti postavio Dean Duda. ${ }^{9}$ Međutim, naš fokus u interpretaciji putopisa »Simfonije Jadrana, Italije, Pariza, Londona« neće biti na tipičnoj književno-povijesnoj ili naratološkoj rekonstrukciji Kosorova teksta, nego na interpretaciji triju misaonih dominanti unutar njegova putopisna diskursa - estetici, duhovnosti, moralu. Ono što u temeljima Kosorovo književno djelo, pa i njegov književni putopis, čini avangardno-ekspresionističkim njegova je utopijska misao. Isto tako Kosorovo djelo primjer je sveprožimanja stilskih formacija prve polovice 20. stoljeća. Međutim, kada u njegovom djelu govorimo o ekspresionističkim tendencijama držat ćemo se označnica C. Milanje koji ovo umjetničko razdoblje iščitava u njegovoj misaonoj cjelokupnosti, a time dakle i pomiče periodizacijske granice samoga razdoblja, što je i itekako važno u kontekstu Kosorove poetike:

»U tom je smislu ekspresionizam esencijalistički, a vidjet ćemo da je i fenomenologijski. To je teizacija univerzuma i religizacija umjetnosti. (...) ... ne univerzum kao strogo konzistentno strukturirana cjelina, nego kozmički patos i zastrašujuća dubina svemira (...) No čim se pitamo o figurama titanističkim, mitskim, s vitalističkim filozofskim implikacijama, ideji nadčovjeka, jednako nazočnih u Krleže kao i u Kosora (...) onda nam se u prvi plan nadaje kategorija energije, shvaćena ekološko-primitivistički, mistično-aktivistički i metodološko-investicijski. ${ }^{10}$

\footnotetext{
${ }^{8}$ Dubravko JELČIĆ, Strast avanture ili avantura strasti, Zagreb, August Cesarec, 1988, 360.

9 »Ključna je pretpostavka književnopovijesnoga pristupa putopisnom diskursu iznalaženje njegovih tipičnih mjesta, oblikovanje svojevrsne retorike putopisa utemeljene na nekoliko oslonaca u rasponu od naratologije do povijesti mentaliteta « [Dean DUDA, Putopis. Od pokušaja određenja žanra do Krležina diskursa, Umjetnost riječi, 40 (1996) 2-3, 76]. Dakle, Duda je u hrvatsku znanost o književnosti unio iznimno valjan interpretativni model putopisnih tekstova: »obrazloženje, itinerarij, putopisni subjekt, leksikon (katalog), dotematizacija, priča i naslovljenik« (usp. Duda, Putopis...; Dean DUDA, Priča i putovanje, Zagreb, Matica hrvatska, 1998).

${ }^{10}$ Milanja, Pjesništvo..., 21.
} 
U konačnici ovako tumačena ideja ekspresionizma uklapa se u tumačenje Dubravke Oraić Tolić o avangardnom utopijskom mišljenju. Čini se da se Kosorovo djelo, pa kada je i o putopisu »Simfonije...« riječ, može iščitavati kroz prizmu utopijskog mišljenja

»koje čezne za uspostavljanjem izgubljenoga ili izgradnjom novoga Jedinstva na svim razinama; (...) u predcivilizaciji (arhajski utopizam) ili će tek biti, u postcivilizaciji (transcendentni utopizam) ${ }^{11}{ }^{11}$

Kroz ove dvije ideje mogli bi se i interpretirati Kosorovi putopisi, međutim $\mathrm{u}$ interpretaciji "Simfonija..." prednost svakako ima »transcendentni utopizam «. ${ }^{12}$ Naime, Kosor nadu (koliko god ona bila krhka u godini 1938. kada putuje Europom!) ipak prepoznaje u neprolaznoj ljepoti pejzaža, povratku čovjeka duhovnosti i duhovnim izvorima te umjetnosti kao kruni duhovne manifestacije ljudskoga postojanja na Zemlji. Iz ideje umjetnosti kao vrhunca ljudske kreativnosti, odnosno o umjetniku kao snažnom subjektu, izrasta i njegova ideja mesijanizma. Dakle, Kosorov putopis nedvojbeno ostvaruje utopijsko mišljenje kako ga je teorijski objasnila Dubravka Oraić Tolić:

»Utopijsko mišljenje i izražavanje osnovna je značajka krizne svijesti i podsvijesti, kriznih i rubnih civilizacijskih stanja, u sustavu kulture ono je dominanta religije i moderne umjetnosti, u sustavu umjetnosti - sinkretističkih žanrova i medija gdje mu je osnovni oblik 'sveukupna umjetnina' (Wagnerov Gesamtkunstwerk).《13

U tom smislu i na stilskoj razini njegovo djelo sveprožimanja žanrova utemeljeno u utopijskoj ideji ne samo obnove nego i spasa svijeta, možemo promatrati kao primjer avangardne »sveukupne umjetnine«. Međutim, kako je bilo najavljeno, interpretaciji Kosorova putopisa »Simfonije... « pristupit ćemo kroz tri dominantna idejna odnosa čija je funkcija realizacija idealne, utopijske slike svijeta unutar književnoga teksta - ali teksta tematski okrenuta opisivanju europske zbilje s kraja 30-ih godina 20. stoljeća. S tim u skladu Kosorovim ćemo putopisima i pristupiti interpretativno u njima iščitavajući njegov »govor o ljepoti« (jadranski pejzaži), »govor o duhovnosti« (talijanska umjetnost) $\mathrm{i}$ »govor o moralu« (pariška demokracija i londonska disciplina). Kolikogod na očigled Kosorov stil djelovao neuhvatljiv i neobuzdan, njegova putopisna knjiga »Simfonije Jadrana... « ima vrlo izraženu cikličnu strukturu.

U uvodu knjige putopisa koju je dodatno odredio podnaslovom »Uvlačenje u se, tonjenje u ponor sebe« Josip Kosor nagovještava obnovu svijeta po ljepoti, stvaralaštvu i umjetnosti, a u odnosu prema neumoljivoj ratnoj zbilji, dok je njegova završna misao putopisa iz Londona zapravo hvalospjev Kristu. Kristu

\footnotetext{
${ }^{11}$ Dubravka ORAIĆ TOLIĆ, Paradigme 20. stoljeća. Avangarda i postmoderna, Zagreb, ZZK FF, 1996, 15.

${ }^{12}$ Kada Milanja piše o Kosorovoj poeziji osobito ističe njegovu sklonost »transcendiranju stvarnosti (usp. Milanja, Pjesništvo..., 131).

${ }^{13}$ Oraić Tolić, Paradigme 20. stoljeća..., 15.
} 
Obnovitelju, Kristu slici Morala, Moralu koji se kao božanska slika Stvoritelja prije Krista očitovao u ćutnji kozmosa; hvalospjev je to obnoviteljskoj slici mesije koji se u zapadnoeuropskoj civilizaciji odčitava u umjetnosti i filozofiji, svojim temeljima koji stoje u kontrastu s materijalizmom koji se najsnažnije očituje u ratu. U tom smislu Kosorovu ideju mesijanizma doista prepoznajemo kao ekspresionističku viziju "preobraženog čovjeka u preobraženom svemiru, novih mogućnosti, nadanja i želja «, ${ }^{14}$ kako je to zaključio I. Matičević. Ekspresionistički utopizam Matičević suprotstavlja ratnoj i poratnoj zbilji Prvoga svjetskog rata, ${ }^{15}$ međutim, Kosorov putopis nastao u samo svitanje Drugoga svjetskog rata, pokazuje da njegova utopijska ideja, koliko god djelovala »nelogično«, nastoji pronaći uporište u osobnoj vjeri u svemogući karakter Pantokratora.

Valjalo bi se prije same interpretacije dotaći i naslova putopisne knjige »Simfonije...«. Unošenje glazbenoga termina u naslov upućuje na ideju avangardne »cjelokupne umjetnine« (Gesamtkunswerk) te nas i uvodi u odčitavanje autorova odnosa prema ljepoti pejzaža, uzvišenoj ideji umjetnosti kao realizaciji duhovnosti te morala kao sveobuhvatne vrijednosti ljudskoga društva.

\subsection{Jadran - simfonije ljepote pejzaža}

U prvoj putopisnoj cjelini posvećenoj južnom Jadranu, što će reći Lapadu i dubrovačkoj okolici, Boki kotorskoj te Cetinju u Crnoj Gori, Kosor je u prvom redu zaokupljen ljepotom pejzaža. Usmjerenost pejzažnim slikama - osobito na samom početku prema ljepoti ruža i lastavica - već na motivskoj razini asocira na wildeovski modernističko-simbolistički esteticizam. Kosor se upušta u prave hvalospjeve lastavicama i ružama koje su živa ornamentika njegova doma, vile Tamariks na Lapadu. I na stilskoj razini ovi su hvalospjevi istkani po načelu modernističke sinestezije pa se i tu može govoriti o autorovoj ideji »cjelokupne umjetnine«. Ljepota pejzaža, konkretno ruža primjerice, autora potiče na sanjarenje nad vlastitim životom, ali i uopće nad idejom kozmosa satkana po savršenim principima prirode. Ljepotu ruža kao sliku mistične »nadljepote« Kosor suprotstavlja materijalizmu rata, slici svijeta vlastite suvremenosti koja je odavna izgubila bitnu vezu s astralnim. Stoga autora ljepota ruža nad kojima onirički zaklapa oči vraća svom vlastitom duhovnom biću u kojem se, kako on to vidi, zrcali savršena slika svemirskog uređenja.

Naslov poglavlja u kojem Josip Kosor tematizira lastavice - »Crno cvijeće vazduha - lastavice...« otkriva da je sinestetičnost jedno od njegovih bitnih

\footnotetext{
${ }^{14}$ Ivica MATIČEVIĆ, Trijumf duše. Knjiga o Kosoru, Zagreb, Ex libris, 2018, 48.

${ }^{15}$ Usp. »(...) vrli novi zavičaj postale su kozmičke daljine kao posljedica bijega od zastrašujuće prakse ratne i poratne svakodnevnice, a onda i od nametnutih normi tzv. građanske kulture - ekspresionisti drže da mogu pojmiti svijet u njegovoj cjelovitosti, a to im daje osjećaj nadnaravne moći, svestvaralačke i sverazorne božanske instancije koja kažnjava staro i kreira novo« (Matičević, isto).
} 
izražajnih sredstava. Lastavice autor i poistovjećuje s ružama i to osobito na razini vlastite duhovne i stvaralačke obnove po slici prirode, njezine ljepote i uzvišenosti.

»Uz ruže i njihov, nečuveni, magični upliv - beskrajno neiscrpivo čuvstvo koje se muči za izraz o njima - i crno, pjevajuće cvijeće vazduha, laste, mnogo su doprinijele popravku moga morala i duševnom uskrsnuću i izvlačenju iz jazbine osamljenosti i pasivnosti na peru. $\ll^{16}$

Ljepotu ruža i simboličku uzvišenost lastavica Kosor uspoređuje s uzvišenom slikom žene koja svojom ljepotom, nježnošću i ljubavlju svijet čini ljepšim i boljim, iz čega se također iščitava modernističko-esteticistički stilski postupak. $\mathrm{Za}$ Kosora je žena slika »morala ruža ${ }^{17}$ koja svijet čini boljim po svojoj ljepoti. Kosor doista utopistički vjeruje u mogućnost obnove svijeta i čovjeka po sinestetičnoj ljepoti ruža u kojoj se ujedinjuje ljepota njezina mirisa s njezinom simboličkom semantikom mistike: »Ja sam uvjeren da miris ruža s hipnozom proročkog uvjerenja mogao bi da nadvlada svebijes i kane balzam kapi mira na jadnu, u atome satrtu, izmučenu ljudsku dušu...«18

Utopijsku ideju obnove i spasenja svijeta Kosor manifestira i kroz filozofsko viđenje Kantove etičnosti zajedno s astralnom, kozmogonijskom idejom Beethovenove glazbe. U ljepoti slike prirode - $\mathrm{u}$ zanosnom sanjarenju nad lastavicama, u Kosorovu se viđenju javljaju i Kant i Beethoven kao misaono-umjetnički, odnosno etičko-estetski stupovi europske civilizacije ${ }^{19}$ dobra. Na ovu dvojicu velikana misli i duha Kosor se asocijativno poziva osobito na putovanjima Italijom, u kojoj umjetnost kao najuzvišeniji ljudski rad povezuje s kreacionističkom slikom prirode i Boga. No, pogledajmo kako je Kosor u simbolu i slici lastavice ujedinio svoju utopijsku ideju svijeta asocirajući Beethovena: »Od sviju zemnih i duševnih elemenata u Beethovenovoj muzici ima najviše nebeskog elementa 'laste'... « ${ }^{20}$ i Kanta:

»Jer je njihova zbilja i krilati, astralni san ljepši, čišći, topliji i nama superiorniji... U časove letimičnog priviđenja, meni se činilo da i sama priroda: pučina, gore, nebo sunce - stoji zablenuta i paralizovana njihovom ljubavlju za svoje mlade... Kako potentno, nadživotno oni njih hrane, kojom brzinom love plijen mušica za njihovu hranu (...) - i 'da nema Boga valjalo bi ga stvoriti' rekao je Kant - i da nema hrane u prirodi - lastavice bi je stvorile i donijele svojim mladima - toliko je u njih ljubavi i magije za odgoj i porast nove generacije... «²1

\footnotetext{
${ }^{16}$ Kosor, Simfonije Jadrana..., 21.

${ }^{17}$ Usp. isto, 18.

${ }^{18}$ Isto, 20.

${ }^{19}$ Usp. promišljanje V. Žmegača uz dvjesto pedesetu godišnjicu Beethovenova rođenja: »Beethovenova je poruka u Devetoj: Bratstvo svih ljudi, ali pod metafizičkim svodom. To se uostalom podudara s tezama Kantove filozofije, koju je Schiller dobro poznavao. Bog je metafizički pojam i etička misao (...)« (Viktor ŽMEGAČ, Godišnjice - prilog Beethovenovoj godini, Vijenac, 2. srpnja 2020, 32).

${ }^{20}$ Kosor, Simfonije Jadrana..., 37.

${ }^{21}$ Isto, 27.
} 
Odnos prema esteticizmu u dijelu Kosorovih putopisnih zapisa južnim Jadranom ističe se, osim promišljanjem ljepote ruža i lastavica, i nadahnutim opisima mora koji su pravi primjer Kosorova fenomenološkoga odnosa prema svijetu. Ljepota mora Kosora potiče na duhovnu obnovu i potpuno duhovno i tjelesno pročišćenje. On se tijekom plovidbe zavjetuje Gospi od Šunja:

»Ovo je bilo po prvi puta da sam uplovio u ovu sutonsku uvalu i impresija je bila takva, da srce trepti i živi dugo i dugo u svetoj uspomeni i potresnom čuvstvu u uvali Šunj ispod crkvice Gospe što snatri tihi raj med mirisnim borovima...« «22

Sličan doživljaj mora Kosor opisuje i u Brsečinama kada Boga primjećuje oko sebe kao sveprisutnu ljepotu čija se prisutnost manifestira kroz estetsku dimenziju pejzaža: »Tu se dragi, biblijski Bog večerom javlja u toplom odsjevu u svaki prozorčić kuće i svakom želi 'laku noć. « ${ }^{23}$

U Kosorovim putopisnim simfonijama Jadrana, a u kontekstu otčitavanja njegove avangardne utopijske ideje svijeta, posebno mjesto zauzima Dubrovnik koji ovoga autora asocira na mesijansku osobnost Frana Supila. On ga doista drži avangardnim natčovjekom. ${ }^{24}$ Uzvišena slika za hrvatsku umjetnost i kulturu mitskoga Dubrovnika po Kosoru je jedina i mogla iznjedriti Frana Supila -

»Dubrovnik nema savremenih spomenika, osim jednog ko svjetionik na pučini Tihog okeana, u sudbonosnoj tišini, Frana Supila, našeg najvećeg političara vizionera i heroja ideja hrvatstva, prahrvatstva.... ${ }^{25}$

Supilu, kojega je Kosor osobno poznavao, o čemu kroz digresije i piše u svojim putopisnim zapisima o Dubrovniku, a kasnije i Londonu, on pridaje osobine ničeanskog natčovjeka: »Supilo je svršio tragično kao što obično svršavaju sve velike eruptivne prirode najsrodnije sudbini Nietzschea...«, međutim kao temeljni razlog Supilova mesijanskog »natčovječstva « Kosor otčitava u estetkoetičkoj dimenziji Dubrovnika i njegove ideje slobode - stoga se može zaključiti da kroz lik Supila Kosor iznjedruje i Kantovu etičku misao o slobodi i republici kao najboljem društvenom uređenju.

Za Kosora su estetsko i etičko neodvojive kategorije, stoga njegovo promišljanje ljepote prirode otvara prostore obnove duhovnosti suprotstavljajući se materijalizmu koji po njemu suvremeni svijet vodi u moralnu i društvenu kataklizmu. Ne čudi stoga završetak njegovih putopisnih simfonija Jadranom kada na plovidbi od Budve prema Dubrovniku i Lapadu pada u potpuni zanos nad ljepotom mora, gubeći vlastitu tjelesnost, padajući u ekstazu nad ljepotom

\footnotetext{
${ }^{22}$ Isto, 66 .

${ }^{23}$ Isto, 62.

${ }^{24}$ Usp. o avangardi, utopiji i natčovjeku kod Oraić Tolić, Paradigme 20. stoljeća..., 83-88, a o mesijanizmu u Kosorovim dramama (ali i dramama drugih eskpresionističkih autora) u radovima Ivice Matičevića objavljenima u knjizi Trijumf duše.

${ }^{25}$ Kosor, Simfonije Jadrana..., 111.
} 
mora, ${ }^{26}$ da bi konačno utočište pronašao u svojoj oniričkoj kući, zasanjanom raju na Lapadu s lastavicama i ružama - »Tamariksu, simboličnoj i edenskoj kuli sanja, vilinske realnosti i nirvanskog odmora... Nu ovaj put Amen za Jadran, ostrva i Tamariks... $\ll^{27}$

\subsection{Italija - simfonije umjetničkih impresija i kršćanske duhovnosti}

Putovanje Italijom za Josipa Kosora čini potpunu opijenost umjetnošću. Ona raspoloženja, misli, ideje zanosa i opijenosti koje je u njemu budila ljepota jadranskoga pejzaža, sada pobuđuje ljepota umjetnosti. Putujući od Dubrovnika parobrodom za Bari, Kosor obilazi Italiju od juga prema sjeveru pritom posjećujući Napulj, Pompeje, Rim, Firencu i Milano, od kuda je sa suprugom dalje krenuo za Pariz. Nakon prvoga dana obilaska Napulja, Kosor otkriva svoje oduševljenje Italijom kao prijestolnicom umjetnosti - prostorom koji dokazuje kreacionističku volju umjetničkoga genija koja djeluje u suglasju s kozmosom, vječnim božanskim redom. Večernja šetnja Napuljom u Kosoru budi zanos nad idejom genija koji svijet stvara po načelu kreacije u ljepoti prepoznavajući domovinu umjetnosti kao vlastitu duhovnu kolijevku: »Po umjetničkom bilu i životnoj žili kucavici, Italija je bila moja umjetnička i vulkanski temperamentna domovina prije negoli sam se rodio... « ${ }^{28}$

Kosor svojim nadahnutim opisima odaje da je Napulj osjetio u punini njegova duha i realizirane ljepote kroz arhitekturu zgrada, palača, dvoraca i parkova, kroz izvrsne gastronomske užitke te ljepotu pejzaža koji se u Napulju očituju kao čarobna kulisa za sve ono što je uspio izgraditi stvarateljski ljudski genij. Kosor iznimno vješto kompozicijski opisuje Napulj po načelu postizanja ideala cjelokupne umjetnine - ujedinjujući dakle sklad slikarske tehnike s dramatikom trenutka opisa i naslućujućom glazbom mora da bi čitatelj stekao dojam cijele napuljske vedute, upravo kao da se i sam tamo nalazi.

»U velebnost Napulja, osim nacionalnog muzeja i Palazzo Reale, osim perivoja, spomenika, promenada po kojima šetaju ukleti u čaru dusi stoljeća, spada katedrala S. Francisco di Paola, koja podsjeća na Pantheon u Rimu, Piazza del Plebiscito, galerije vila i palača uspetih na brjegove, odakle dominiraju nirvanski vidici na vječno uzrujanu pučinu Tirenskog mora, zatim viši, neograničen vidik u gornjem 'Napoliju' do koga se dolazi uspinjačom, a koji se zračno, dimno

\footnotetext{
${ }^{26}$ Izlaženje iz sebe, odnosno tjelesna reakcija nad ljepotom doživljenoga u putopisnim se zapisima počela javljati pod utjecajem Kantove filozofije, što u potpunosti dokazuje Kosorov svjetonazor u kojem su estetsko i etičko u simbiotskoj vezi [usp. više o važnosti estetskoga mišljenja u putopisnoj književnosti u: Mary-Ann CONSTANTINE, Aesthetic, u: Ch. FORSDICK, Z. KINSLEY, K. WALCHESTER (ur.), Keywords for Travelwriting Studies. A Critical Glossary, Anthem Studies in Travel, 2019].

${ }^{27}$ Kosor, Simfonije Jadrana..., 169.

${ }^{28}$ Isto, 178-179.
} 
i vatreno grli s Vezuvom beskrajem morskog horizonta, magičnim, čeznutljivim opisima Caprija, Sorrenta i ostalih ostrva i kaštela u moru... « ${ }^{29}$

Prije posjetu Rimu Kosor odlazi u Pompeje. Rimski grad koji je ostao konzerviran ispod nanosa pepela i lave iz Vezuva, Kosora zaustavlja u promišljanju tajni života i smrti, kataklizmi i kazni, prirode i morala. Asocirajući Dantea šetnjom kroz Pompeje Kosor postavlja pitanje od koga tražiti odgovornost za prirodne kataklizme dovodeći ih u neposrednu vezu s ljudskim zločinima koji su u stanju uništiti čitav svijet.

Doživljaj Italije kao prijestolnice umjetnosti i umjetničkoga genija već samim ulaskom u Rim Kosor suprotstavlja suvremenoj ratnoj (pred)zbilji. Svijest o ljepoti i izgubljenom raju postaje motiv koji Kosora pokreće na promišljanje civilizacijskoga pada čovječanstva. Ideja umjetničkoga genija realizirana u formi natčovjeka i mesije-obnovitelja mogla bi se zapaziti kao dominantan doživljaj tijekom Kosorova boravka u Rimu. S jedne strane ona se utjelovljuje u slici velikih umjetnika i velikih umjetnina, a s druge u slici Krista - nositelja duhovne snage, otkupitelja i spasitelja, nositelja solarne snage koja nadjačava tamu. ${ }^{30}$ Međutim, toj slici Kosor suprotstavlja u Rimu asocirana Nerona kao preteču obrnute slike »natčovjeka« koji je poput suvremenih tirana, sotonski uništavao život, ljepotu, ideju kozmosa kao sklada čovjeka i zemlje. ${ }^{31}$ U Rimu se Kosoru potvrđuje i učvršćuje spoznaja da je u umjetnosti estetika neodvojiva od mistike, duhovnosti. Umjetnički genij u tom smislu za Kosora čak nadvisuje same osobe svetaca u čije ime umjetnici stvaraju iz prazne materije »novi život«. Michelangelo je za Kosora prava, istinska slika sv. Petra jer:

»Crkvom svetog Petra dominira skoro više Michelangelo negoli sveti Petar i udiv umjetnički tuče skoro na svakom koraku religiozni... U svim skoro crkvama talijanskim, i uopće u svim crkvama tuku umjetnici svece il' ih obraćaju u umjetnike. ${ }^{32}$

Kosor u zanosu gledajući Michelangelova Mojsija sav treperi promišljajući snagu umjetnosti i kreacije i sam - poput Michelangela - želeći narediti Mojsiju nastalom iz hladne i mrtve mramorne gromade neka progovori. Zanos nad Michelangelovim genijem Kosora misaono vraća u domovinu - promišljajući hrvatske, suvremene, umjetničke genije - Ivana Meštrovića ${ }^{33}$ i Antuna Augu-

\footnotetext{
${ }^{29}$ Isto, 184.

${ }^{30}$ Vidi o slici Krista u Kosorovim dramama radove I. Matičevića »Svjetlo duše - figura promjene u dramama Josipa Kosora« i »Zaboravljeni Bog u Kosorovoj drami Ima Boga - nema Boga«, Trijumf duše, 65-106.

${ }^{31}$ Usp. »Nero je prototip M. H. S. i monstrum-kriminalnog Japana koji su novovjekom tehnikom i robotskom, mašinskom nečuvstvenošću natkrilili milijune i milijune Nera...« (isto, 230).

${ }^{32}$ Isto, 208.

${ }^{33} \gg$ Kad je govor o majstoru vječnosti, nuždnoj asocijaciji ideja ne mogu i da ne spomenem našega Ivana Meštrovića. (...) On je uvaljao dinamiku naše Adrije i dinamiku naše okeanske duše» (isto, 209).
} 
stinčića ${ }^{34}$ - držeći ih upravo ravne Michelangelu po snazi, zanosu, širini. U asocijativnom doživljaju umjetnika ogleda se Kosorova utopijska ideja obnove - prevlast duhovnoga i estetskoga nad mrtvom prazninom materije - »Jer jedna nacija ne postoji nacijom po broju stanovnika nego po visokim kvalitetama stvaralačkog duha... « ${ }^{35}$ Umjetnička osobnost Michelangela u Kosorovu je doživljaju preuzela sliku Rima; Michelangelu je samo u glazbi ravan Beethoven koji je »svojim simfonijama ganuo sva tjelesa i duše i srca u prostoru...«, ${ }^{36}$ drži Kosor, dok umjetnost Sikstinske kapele predočava ne u opisu slika (dapače, onaj tko ne poznaje Sikstinsku kapelu od Kosora ne bi ni mogao saznati što se tamo nalazi), nego u doživljaju duha. Ljepota kao doživljaj po sebi postaje mjerilo opisa Sikstine u stilu izravne ekspresije u kojoj je lik umjetnika-genija nadređen samom umjetničkom ostvarenju. Nakon boravka u Vatikanu lik genija, mesije i natčovjeka Kosor pretače u viziju Krista koja mu se ukazuje u umjetničkim vrhuncima Bazilike sv. Pavla pa cijelim Rimom sve do Vie Appie gdje asocira sliku sv. Petra i Krista, kada po tradiciji sv. Petar uskrsloga Krista pita: »Quo vadis, Domine? « Kosor Krista vidi kao svemirsku, astralnu, sveobnoviteljsku snagu. On ga ne gleda kao raspeta mučenika, nego snažna, ekspresionističkoga obnovitelja. Slikom Krista Kosor na mističnoj, duhovnoj razini uspijeva realizirati ideju utopijske obnove svijeta - jer po Kristu nastaje umjetnost, najuzvišenija slika ljudskoga postojanja. Izdvojit ćemo nekoliko vrlo dojmljivih Kosorovih misli i doživljaja Krista koje je u njemu pobudio Vječni grad, prijestolnica univerzalnog katoličanstva:

»U najbožanskijoj, najveličajnijoj formi Krist je ugrađen u Pavlovu baziliku, koja šalje stožerne valove svijetla u vasionu: 'Oče, oprosti im, jer ne znaju što čine.' Tom zadnjom njegovom izrekom Istina je analizovala Svezločin (...) nu nada sve diže se Krist svojom nadsolarnom vizijom... elektricitet njegova tijela kao da je bio van domaka našeg sunčanog sistema, kao da je dokučio najviši stepen vječne supstancije... ${ }^{37}$ (...) On koji u tijelu nije osjećao tijela bio je sobom kao svemirom svjestan da je sin Božji, da je duhom i dušom sinteza Svebiti... Krist nije solarni slučaj nego sinteza vasionske mistike, poezije, duha i kreatorske supstancije. On je najsavršeniji izraz svemira, najveći, najumjetničkiji.« ${ }^{38}$

Dolazak u Firencu za Kosora je bio ulazak u prijestolnicu umjetnosti. Zapravo, Kosorov putopisni zapis iz Firence i jest njegov hvalospjev umjetnosti i umjetnicima - »Firenca je domovina sviju velikih duhova.$^{39}$ Boraveći u galerijama Pitti i Uffizi Kosor ispisuje niz refleksija i dojmova nad onim što vidi, u osobitom dojmu Tizanova djela asocira ponovno Beethovenove simfonije kao

\footnotetext{
${ }_{34} \gg$ Njegova dinamika puca žestinom i baca blještave iskre uz magiju linija i beskraj valića forama

- ko ispod čekića gigantskog kovača...« (isto, 211).

${ }^{35}$ Isto, 209.

${ }^{36}$ Isto, 213.

${ }^{37}$ Isto, 216.

${ }^{38}$ Isto, 218.

${ }^{39}$ Isto, 238.
} 
jedinu glazbu koja može dočarati silinu umjetnosti i ljepotu koja se čuva u ove dvije galerije, u Firenci kao čarobnom gradu umjetnosti. U svojevrsnom paralelizmu misli Kosor analizira čovjeka kreatora i čovjeka zločinca vjerujući da je umjetnički genij toliko jak da može promijeniti svijet, da ga može izliječiti, zločinca povratiti u čovjeka.

Josip Kosor svoje putovanje Italijom zaključuje u Milanu. Oslobođenje od rata i zla on pronalazi u kršćanskoj mistici, u evanđelju i teološkoj literaturi (»)a sam toga dana i sve sljedeće dane i mjesece, od časa do časa, čitao Thomasa de Kempisa Imitaciju Krista i divio se Kempisu koji je produbio evanđelje...«)..$^{40}$ Milano, kao završna točka njegova puta po Italiji, u njemu je probudio spoznaju da je kršćanska duhovnost temelj preobrazbe svijeta i njegove konačne obnove.

\subsection{Pariz i London - transcendiranje utopijske misli}

U itinerariju puta po Europi Josip Kosor i supruga Ljubica imali su uključen put u Pariz s namjerom odlaska na svjetsku izložbu - što je po pisanju autora, u njemu izazvalo osjećaj nemira i neke neobične strepnje. Pariška izložba te asocijativno promišljanje hrvatske suvremene umjetnosti i uopće položaj umjetnika, središnja je tema kojom se Kosor bavi u svojim »pariškim simfonijama«. Dakako da ga pariška atmosfera i uopće "grad svjetlosti« asocira na francusku slobodu duha i utopijsku ideju ujevićevskog »pobratimstva u svemiru«: »U pariškoj atmosferi duh se vedri i jača, pesimizam iščezava i čovjek osjeća neko duboko bratimljenje s čitavim svijetom. « $^{41}$ Gotovo odvojen od zbilje on promišlja molitvu, ulogu vjere u ljudskom životu da bi svu bujnost svojih asocijacija u konačnici sažeo u utopijsku misao obnove po načelu slobode duha. Grad svjetla ponudio mu se kao vjera u svjetlo (»Pariz je meni što je suncu žar i svjetlo...«), ${ }_{4}^{42}$ stoga ga napuštajući, englesku obalu, Dover i London vidi kao blijedu i bijelu, bjelinu koja ga odvodi u neke nove $»$ sjeverne ekstaze ${ }^{43}$

Boravak u Londonu za Kosora je svojevrstan povratak kući, što dijelom i jest činjenica, a to je možda i razlog što je putopisni zapis posvećen Londonu ujedno i najkraći te se u njemu gotovo i ne prepoznaje standardna putopisna forma. Govoreći o engleskom mentalitetu i zašto je on drag njegovoj supruzi, posljednju simfoniju sa svojega putovanja Kosor posvećuje govoru o etici i moralu. U konačnici bi se i moglo zaključiti da je svoju putopisnu knjigu Josip Kosor koncipirao kao književnu simfoniju u četiri stavka - od južnog Jadrana i Italije, koji su u Kosoru probudili simfonijsku vatru ideje esteticizma i duhovnosti, do Pariza i Londona koji su je zaokružili smirenim slikama svjetla i morala. Boravak u Londonu za Kosora je zapravo duhovni povratak antičkom

\footnotetext{
${ }^{40}$ Isto, 277.

${ }^{41}$ Isto, 296-297.

${ }^{42}$ Isto, 319.

${ }^{43}$ Isto, 324.
} 
Mediteranu, od starogrčkih filozofa do konačnog spoznanja istine u Kristu. Stoga završna riječ njegovih putopisnih simfonija i jest velika pohvala moralu: »Sve velike kulture i umjetnosti potekle su iz velikog osjećaja i daha morala koji uključuje uz etičke i estetske zakone, koji traže kozmično uposlenje, zabavu. « ${ }^{44}$ Dakle, utopijska obnova svijeta, po Kosoru je harmonija estetike, duhovnosti i morala.

\section{Zaključak}

Interpretacija putopisa Josipa Kosora »Simfonije Jadrana, Italije, Pariza i Londona " temeljila se na analizi triju dominantnih ideja Kosorove utopijske misli - estetici, duhovnosti, moralu. U putopisima posvećenima južnojadranskim pejzažima Kosora njihova ljepota potiče na obnovu duhovnosti, novom pročišćenju čovječanstva, dok se u putopisima posvećenima talijanskim gradovima, umjesto pejzaža, nameće ljepota i uzvišenost umjetnosti, kao poticaj za utopijsku misao obnove svijeta. Ljepotu pejzaža i ljepotu umjetnosti kao sjedinjenje božanskoga i ljudskoga dara, Kosor u konačnici u svojim meditativnim zapisima o Londonu zaključuje mišlju o nasušnosti etičke dimenzije u životu civilizacije držeći da je ona temelj utopijske obnove svijeta. U putopisnim zapisima o južnom Jadranu (Dubrovnik, Boka kotorska i okolica) Kosorovi su iskazi pravi primjeri modernističkoga esteticizma; u talijanskim putopisima njegova utopijska ideja obnove temelji se na promišljanju umjetničkoga genija kao najuzvišenije slike ničeovskog Natčovjeka, dok u podosta kraćim putopisnim zapisima Parizom i Londonom autor sumira doživljaje prirodne i umjetničke ljepote te temelj društvenog morala pronalazi u francuskoj slobodi duha i engleskoj discipliniranoj uređenosti života. Avangardni utopizam, kao jedna od označnica ekspresionističke dimenzija njegova putopisna djela prepoznaje se $u$ realizaciji ideje »cjelokupne umjetnine« kao i bujnom, manirističkom stilskom izrazu. Uz to, vrlo izražena ideja mesijanizma (npr. promišljanje o F. Supilu u Dubrovniku, o Michelangelu u Rimu, o Tizianu u Firenci) kao i slika Krista kao snažnog obnovitelja svijeta (npr. asocijacije iz Milana ili finale putopisa iz Londona), Kosora svrstava u red avangardno-ekspresionističkih utopista. Interpretacija njegova putopisa »Simfonije Jadrana, Italije, Pariza i Londona«, koji je hrvatskoj javnosti prvi put postao dostupan nakon više od sedam desetljeća, pokazuje da je Kosor svoj osebujan stil i avangardnu utopijsku ideju obnove, u hrvatskoj historiografiji prepoznate u njegovim dramama, poeziji i prozi, nastavio njegovati i u svojim poznijim zapisima, pa čak i u tekstovima žanrovski hibridnog, putopisnog obilježja.

${ }^{44}$ Kosor, Simfonije Jadrana..., 355. 


\section{Sanja Knežević" \\ World Resurrection as an Utopian Idea in the Travelogue »Symphonies of the Adriatic, Italy, Paris and London" by Josip Kosor \\ Summary}

In the paper is interpreted the travelogue »Symphonies of the Adriatic, Italy, Paris and London « by Josip Kosor in the key of the expressionist and utopian idea of the world. The beauty of the landscape, art, vision of messianic personalities, and finally the reflection of ethics as inseparable categories of beauty, encourage the author to reflect on the aesthetics and mysticism.

Key words: aesthetics, Croatian travelogue, Josip Kosor, morals, spirituality, utopia.

(na engl. prev. Sanja Knežević)

\footnotetext{
* Sanja Knežević, PhD, Assoc. Prof., University of Zadar, Department for Croatian Studies; Address: Obala kralja Petra Krešimira IV/2, HR-23000 Zadar, Croatia; E-mail: sknezev@unizd.hr.
} 